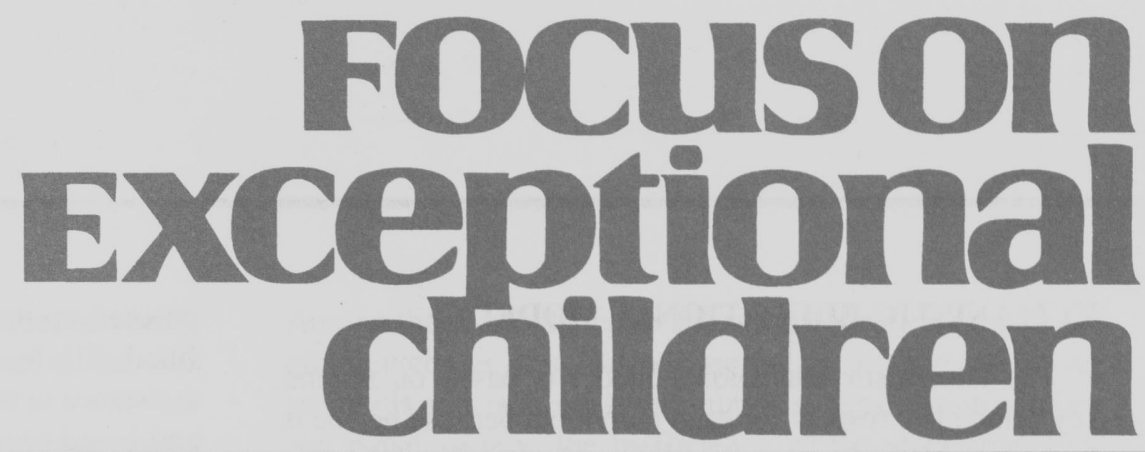

\title{
Society and Disability: A Model of Support in Special Education and Rehabilitation
}

\author{
Shunit Reiter
}

It is time to ponder the future and look at new paradigms in special education and rehabilitation. This article will discuss three influential models or approaches that have impacted the field throughout history. The purpose of this examination is to provide a systematic fourth model which is a combination of the three models.

\section{SOCIAL AND WELFARE MODEL}

The social-welfare model emphasizes the need to provide basic care to help people who are sick, elderly, or disabled. The goal of this approach is to support the physical and existential needs of the individual. Decisions about services are made by classifying people into groups or categories; treatment is provided according to rules and regulations. The orientation allows for only limited involvement of the "client" or the family in the decision-making process or in the treatment. Relationships between the service provider and the "client" are nonsymmetrical. The client is dependent on the service provider and is expected to comply. The advantage of this approach is that it provides for the basic needs of children and adults with disabilities.

\section{SCIENTIFIC-MEDICAL MODEL}

The scientific-medical model is based on scientific thinking about health and disease. The service provider, be it the physician or therapist, views the client as a person who is sick and needs treatment. The purpose is to cure the disease and to assist the patient in reaching a level of optimal functioning. The patient and the family again have limited choice. The advantage of this model is its emphasis on the individual's health.

Shunit Reiter is Professor of Special Education, University of Haifa, Israel. She is the author of Society and Disability: An International Perspective on Social Policy published by AHVA Publishers in Haifa, Israel. 


\section{HUMANISTIC-EDUCATIONAL MODEL}

The humanistic-educational model is based on several key principles: respect for each individual because he/she is human, and because humans are capable of rational thought and self-control and regulation. Furthermore, each individual has the right to be different and live life according to his/her chosen personal style and unique needs. The relationship between the service provider and the client is based on a mutual dialogue between two equal autonomous individuals, namely a relationship of "You and me".

\section{A COMBINED MODEL-THE HIERARCHY OF HUMAN RIGHTS FOR WELFARE, HEALTH AND EDUCATION}

Each of the three models has resulted in benefits, as well as drawbacks, to the lives of people with disabilities. This article will highlight the positive impact that each model has for improving services for persons with disabilities and show how a paradigm based on a hierarchy of the three models can be formed to create a new concept of supportsystems. The concept of a hierarchy implies that one cannot

\section{Focuson
Exceptional
childiren}

ISSN 0015-511X FOCUS ON EXCEPTIONAL CHILDREN (USPS 203-360) is published monthly except June, July, and August as a service to teachers, special educators, curriculum specialists, administrators, and those concerned with the special education of exceptional children. This publication is annotated and indexed by the ERIC Clearinghouse on Handicapped and Gifted children for publication in the monthly Current Index to Journals in Education (CIJE) and the quarterly index, Exceptional Children Education Resources (ECER). The full text of Focus on Exceptional Children is also available in the electronic versions of the Education Index. It is also available in microfilm from Xerox University Microfilms, Ann Arbor, MI. Subscription rates: Individual, $\$ 30$ per year; institutions, \$40 per year. Copyright (C) 2000, Love Publishing Company. All rights reserved. Reproduction in whole or part without written permission is prohibited. Printed in the United States of America. Periodicals postage is paid at Denver, Colorado. POSTMASTER: Send address changes to:

$$
\begin{gathered}
\text { Love Publishing Company } \\
\text { Executive and Editorial Office } \\
\text { P.O. Box } 22353 \\
\text { Denver, Colorado } 80222 \\
\text { Telephone (303) 221-7333 }
\end{gathered}
$$

Karen Harris

University of Maryland
Thomas Skrtic University of Kansas proceed up the ladder, unless certain earlier stages are fulfilled. The basis of the proposed hierarchy are rights for assistance in the area of survival as it has been derived from and based on the custodial-welfare model, followed by the rights for health and treatment based on the scientificmedical model and, at the top of the hierarchy, rights for autonomy and self-actualization, based on the humanisticeducational model.

\section{The Origins of Social Welfare Policy in the Custodial-Welfare and Scientific-Medical Model}

The three major ways of looking at human beings and their place in the universe that have been identified here-the custodial, the scientific and the humanistic-co-exist nowadays in the Western world, influencing policy and practice toward people with disabilities. Each holds a different concept of one's place in the world, a different outlook of the role of the person in society and the role of society toward the person and, in particular, the person with a disability.

Can the three be unified into one single whole? Apparently the answer is negative. Each point of view leads to a specific and coherent set of values. Indeed, each stands by itself as a separate entity. Furthermore, in reality one finds that each is typical of a certain service or a certain social institution. Historically, the emergence of each, in theory and practice, has resulted in the creation of new social structures. For example, the custodial-welfare model has evolved as part and parcel of the religious institutions, such as monasteries and almshouses, that started to spread over Europe during the old Roman Empire; or the medical and related treatments of human illnesses as they evolved in the hospitals, institutions that were first established already in the ancient Greek world about 200 years before Christ; or the humanistic model that is generally found in educational institutions. The last can be found in the unique achievements of individuals who created residential or day schools such as the old Greek Academy, run by Plato, and up to more recent establishments such as the residential school, the Neuhoff, which was opened and operated by Pestalozzi (1746-1827) in Switzerland and was aimed specifically at children from deprived social groups, mainly the poor.

Each model is therefore typical of a certain kind of a social establishment. If this is the case then several questions emerge: First, is one model "better" than the others in giving answers to the needs of people with disabilities? Second, should we try to change the current situation? Third, if we wish to introduce a change, what kind of a change should it be?

Is one model "better" than the others?

The answer to the first question of the superiority of one model over the other two calls for a value judgment as well as a consideration of current trends in relation to persons with disabilities. 
In order to answer, let us first look at the special contribution of each model to people in general and those with disabilities in particular.

The greatest contribution of the custodial-welfare model lies in the principle according to which the one that has more should give to the one that has less. Religion introduced the concept of welfare to the ancient world of more than 2000 years ago. Nowhere else in the old world was there a law by which the rich had to give to the poor. This social approach was an innovation introduced by Judeo-Christianity and has since become embedded in all modern secular Western nations. This notion of help is not only a matter of technical aid but, as described in both the Old and New Testaments, is accompanied by feelings such as compassion, genuine care, pity, mercy, goodwill, stretching out a helping hand to anyone in need. This emphasis on feelings is significant because it is only too easy to ignore the weak, to make fun of someone different, to ridicule the deformed, to reject the stranger. It is therefore important to note this additional contribution of religion, which implies that the giving should be done with good will, accompanied by benevolent feelings and an outward expression of the wish to give and the wish to help the person in need. The giving is not something to be done in a haphazard way or through benevolent donations only. Religion stipulates two conditions:

First, giving is a duty and a responsibility of the community; it must be based in law. Society has the duty to distribute its wealth so that those who have more will pay taxes that are designated for helping those in need. It is also clearly stated in the Scriptures that it is the duty of those in need to accept the help. Second, the giving should be organized systematically: the collection of fees and goods, their allocation to preassigned individuals and groups according to written regulations and, finally, organizing the distribution of goods.

In Western democracies the beginnings of social welfare policy and services, including health-care, education, minimal income, and shelter, can be found at the end of the 18th century. The social order changed from a conglomerate group of classes to an individualistic society, composed of individual citizens and founded on legal rights. After World War II social welfare policy had an accelerated development. It was expressed in more state spending on social services, the initiation of new schemes, intervention programs that tackled a large array of social problems and direct involvement of the government in providing various social services. During the 1970s and the 1980s this acceleration was restrained and, in some instances, government spending was reduced.

Indeed, some experts maintain that social welfare is collapsing. Katan (1994) suggests a list of possible reasons for decreased governmental involvement in social services.
Among these are: the criticism heard concerning the negligible outcomes of social welfare policy in terms of curing social ills and its limited contribution to the creation of a just and equal society; the inefficiency of the state apparatus, mainly bureaucratic, to deal with social issues. Rather than curing poverty, for example, the state creates a dependency on social security money and thus, in a way, increases poverty by encouraging dependency rather than independence; the economic burden of social welfare endangers the financial stability of the nation; most social welfare countries are currently in a state of economic crisis; a political change in the balance of power between Socialist parties and Liberal or right-wing parties have also led to the reduction in governmental spendings on social welfare. On the other hand, Katan also points out that there are several factors that counterbalance the forces that limit social welfare and contribute to its strength and development. Among these factors are the support and demand for the continuation of a social welfare policy by constantly growing sectors in the community, the recipients of these services, such as pensioners, poor and displaced families, people with disabilities. Some of these groups have significant political power. Another source of pressure for the continuation of social welfare policy comes from the numerous professionals and non-professionals working in the field who are convinced of the duty of society toward social welfare. The tradition of social welfare found in Western countries is still deeply embedded in local culture and expectations from the government. In addition, many of the services provided by the state are based in the law, a fact that complicates any changes.

Two major forces can be identified nowadays as operating for the maintenance of social welfare policy and services. One is cultural: it is the general public agreement that the state has a responsibility towards its citizens. As we have seen in the custodial-welfare model, the conception that the strong are obliged to help the weak is a deep-rooted cultural imperative of Western thought. Though changes and modifications can occur in the way this imperative is interpreted, the principle underlying social welfare and the personal security it affords citizens is strongly held (Elliot, et al., 1991).

The second force that strengthens rather than weakens social welfare is economic and lies in the rise of the Third Sector which includes nonprofit organizations, voluntary associations, and small private services for profit that are sub-contracted by the government in the social areas. The emergence of the Third Sector-the operation of nonprofit organizations that provide help and assistance in the social areas-gained in importance and in significance in most Western countries, during the 1980s and the 1990s, and currently it is playing a key role in the provision of social 
services. Through the non-profit organizations, a large variety of services is delivered, some of which were originally under the responsibility of the state. Indeed, in most instances there is a partnership between the government and the non-profit organizations in areas such as health care, education, culture, and recreation. This sector is composed primarily of small and medium-size organizations. The rise of the Third Sector is, to some extent, an answer to the failings of the old social welfare policy and services; it leads to a higher level of participation of consumers in the services they receive, and more focused assistance according to personal needs as well as activities in the area of self advocacy.

The scientific-medical model has added the dimensions of research and technology to social services. It has also contributed to the scientific inquiries that predominate in many of the services and the way they are rendered to certain sectors of the population. The basic principles underlying the scientific model are well known: in the first stage there is a formulation of tentative assumptions regarding the phenomenon (or the person) under investigation, analysis of findings according to a certain theory, diagnosis and labelling followed by prognosis as to the future course of events. The next stage is based on prescription of methods of intervention, examination of the effects of the intervention program, and conclusions. Apart from medicine, many vocational rehabilitation centers, special education programs, and psychotherapies operate according to these guidelines. Medical care has contributed and still contributes to the physical well-being of many people, including those with disabilities. Since the 18th century, health, like welfare and education, has become a matter of national concern. It is one of the services provided, in one form or another, by Western states to their citizens.

Unlike the other two approaches, the humanistic-educational model has not been identified with specific social institutions. It is, nevertheless, the theoretical basis for current democratic policies as well as the written law on which many modern Western nations are founded. Humanistic notions were an important background to the French revolution of 1789 and its slogan: "Liberty, Equality, Fraternity".

Apparently, the answer to the question we posed earlier, whether one model is better than the others, is negative. In fact the truth is there is no such thing as a "better" model: each has developed an impressive array of social institutions that have contributed enormously to the advancement of Western civilization. Each provides answers to a different set of questions. The custodial-welfare model gives answers to questions of right and wrong conduct; the scientific-medical model provides answers to questions of health and sickness, normalcy versus deviancy; the humanistic-educational model answers questions relating to basic human rights and to questions of justice versus injustice. Thus, it appears that all three models will continue to have their impact on people's lives, contributing to their physical and material welfare. Modern democratic nations are based on written laws that protect the citizens. Why, then, should we aim to introduce any change in the present day system?

The answer lies in the point raised by the critics of social welfare-the general inefficiency of the system which, at times, achieves the opposite rather than its professed and formal aim. Rather than fostering greater independence and health, we find in many cases greater dependence and unhappiness leading to violence and despair. Many voices calling for change are heard today both from service providers and service recipients. In a most eloquent presidential address to the American Association on Mental Retardation in 1993, Michael Dillon (President, 1992-1993) addressed the need for change in his speech: "Morality and Freedom: Challenges to a Field in Transition". Some citations will demonstrate the present call for change: "In our lifetime, we have seen enormous changes in our society and in our field. Indeed, great strides have been made. . . (However) we change specific practices but seem to miss the greater principles involved. Changes can occur in many ways. We are mercifully emerging from a period in which the preferred means of correcting wrongs or accomplishing the good was attempted through the promulgation of rules. . . Rules beget more rules, beget rule books, beget volumes of rule books. It is true that our rules have corrected some situations or unwanted practices. The problem with rules is that they do not necessarily lead to an understanding of the principles involved nor the reasons for creating the rule or regulation in the first place. . . Our field is, thankfully, moving away from superstitious rule-following rituals to more flexible guidelines that require an understanding of the issues involved. This approach demands our most moral thoughtful judgment. . . We cannot escape the wrenching and frequent conflict between the rights of the individual and our system of societal rules and customs" (ibid, pp. iii-v).

Lately, we also have witnessed, along with the call for change, the beginning of actual modifications in the social welfare services, in education and in the medical, psychological, and other health services. In fact, over the past half century, there has been a gradual recognition of the human needs for personal development and for psychological growth of persons with disabilities. This has been demonstrated by the change of social policy from institutionalization to community integration and inclusion, the change in special education from segregation to mainstreaming, and the development of a large variety of psychotherapies that focus on the treatment of emotional and mental disabilities.

Calls for change are now also being heard from consumers of services. Indeed, persons with disabilities and 
their families are in the front line of social change in this area. This is partly a result of the demands that persons with disabilities will be directly involved in decisions concerning their programs. The field of services has been "moved away from an almost dictatorial situation in which professionals knew what was 'best' for people and into a situation in which consumers are guaranteed involvement in decisions affecting their lives. Other examples of this move toward individual, family, and community empowerment include practices such as 'circles of support', citizen advocacy programs, and the mandatory presence of consumers on various decision-making bodies, such as state development disabilities councils" (MacFadden and Burke, 1991, p.ii).

The concept of normalization, introduced during the late 1960s, has brought about an impressive change in the outlook toward people with disabilities as, first of all, normal persons and only afterwards as people with disabilities. The most outstanding effect of this changes was in the enactment of civil laws and the international declaration of the equal rights of persons with disabilities.

All these changes have had an effect on the need for a re-assessment and analysis of the conventional models of services: the custodial-welfare model and the scientificmedical model with a raised interest in the humanisticeducational model. The concept of quality of life, which has in the past decade replaced the concept of normalization as the guiding philosophy of policy and services, has also led to a certain rethinking of the kind of services with which persons with disabilities are provided.

As noted in the first section, several general principles are currently accepted in most Western countries as the guidelines for the development and running of services to those with disabilities. These are:

- Human rights applied equally to people with disabilities

- Empowerment of persons with disabilities

- A person-centered approach

- Inclusion in the community.

It is also generally appreciated that in order to achieve the above, education should start from an early age: education that applies methods to enhance the ability of the individual to make the best of his human rights takes advantage of his "empowerment", develops personal autonomy, and enters into meaningful and mutual interpersonal relationships. None of the above can be measured quantitatively only; each implies a qualitative personal development based on processes. Without suitable education, these will not occur.

As regards the three models, the question that should be asked is: to what extent does each one answer the above principles?

Examining each model, one finds that the interpretation of the above principles-rights, empowerment, a person-centered approach and inclusion - is different. In both the custodialwelfare and the scientific-medical models the client is seen as an object to be cared for and manipulated by "responsible superiors". These superiors are either appointed by society and answerable to it or they acquire their role through professional qualifications. Their first responsibility is therefore toward their profession. This approach does not enable clients to have full control over their fate, their treatment, or their living conditions. The caretakers relate to them as members of categories. Clients are allowed only to a limited extent to express their own particular personalities. Normalization is seen as adaptation by the client to the requirements and norms of the caretakers or the professional authority. Emphasis is placed on the client's acceptance of the conditions provided (Gunzburg and Gunzburg, 1991). Policy-makers, practitioners, and professionals regard Quality of Life as identical to accepted standards of living and of health-in other words with the physical and external conditions of living.

In contrast, in the humanist-educational model, the client is seen as a person, as a subject with a unique personality and, as such, has the inherent right to be respected. Service providers, at all levels, from the general macro level of policy-making down to the care and treatment of the individual, are engaged in continuous dialogue with the client. The "client" takes part in decisions concerning fate, choice of treatment, planning the future. The style is that of partnership, the right of the individual person to express personality and to actualize tendencies, interests, and talents. Ambitions and hopes rank foremost among the values shared by "clients" and service providers. The concept of normalization is seen as a process, an ongoing struggle of decisionmaking on the basis of internalized values. It is seen as the right of the person to lead a life of choice, selecting from alternatives. Integration in the existing society is founded on personal consideration and knowledge. A person's way of functioning is seen as a composite of personal willpower, ability, and skills acquired, and their adaptation to existing possibilities. Quality of life is judged by service providers, "clients" and their families as based on a set of internalized values leading towards a life of quality. The term "standard of living" refers to physical, external conditions only.

Apparently, while the custodial-welfare model emphasizes the physical existence of the person, the scientific-medical model emphasizes physical well-being, the humanisticeducational model differs from them in that it emphasizes the overall personality of the client. This model is based on the idea of a "life of quality" as the basic right of everyone and also the unquestionable right of those with disabilities (Reiter, Asgad, 1992).

The answer, then, to the first question concerning the superiority of one model over the other, is that the humanisticeducational model seems to give the fullest answer to the 
current guiding principles in the policy and practice of services to persons with disabilities. This model also answers best the new issues that they themselves bring up, mainly their wish to be the masters of their own lives in spite of an obvious physical and sometimes mental or emotional dependency on others in society. In the past decade this trend has received an impetus as more and more people with disabilities are included in everyday community life. It can be seen in the numerous self-help groups that have emerged. It is also seen in recent legislation concerning people, adults and children, with disabilities-legislation based on humanistic philosophy.

\section{Human Rights and the Humanistic-Educational Model}

In ancient times the humanistic-educational model was the special privilege of the rich or the few who did not care for material goods. At the end of the 18th century, new demands arose for written legal systems of civil rights. Services based on concepts and principles derived from the humanistic-educational model have since been translated into the legal systems regarding the rights of all citizens, i.e without neglecting the rights of citizens with disabilities.

The concept of human rights implies the entitlement to certain rights. Which ones? Those based on the humanistic concept of people and their basic natural needs. It is assumed that basic human rights are common to all and are therefore universal. These rights should ensure natural justice. They precede any particular legal system. This calls for appropriate arrangements that will ensure that the interests of each and every person for a life of dignity, freedom, and equality irrespective of race, religion, sex, nationality, and any other consideration that is not relevant to human nature are not respected.

A distinction is made here between two sets of natural human rights: one relates to civil rights, the other to social rights. Civil and political rights were historically the first to receive recognition. They included the right to be active in political campaigns, freedom of speech, freedom of thought, freedom to exercise whichever religion one chooses, freedom of movement. The essence of these rights is that society is expected to refrain from limiting individuals from doing as they please, the right to lead life the way they choose even if it means being different. The demand made on the state is negative-_Don't interfere!" An additional demand is the one for a fair hearing in cases in which any of the above rights is infringed, the right for legal defense, and the right to be told of the reasons for constraints. Indeed, the existence of courts in a legal system, and the need to ensure the independence of those called upon to operate within those courts are fundamental to modem society and the rule of law. The other areas are those of social and economical rights, including basic conditions for survival such as food and shelter as well as education and health.

Another feature of human rights is the implication of duty. One person's rights are the obligation to a particular behavior by the other, and vice versa. Thus, the fulfillment of both the civil rights and the social and economic rights is the duty of the state, which is expected to safeguard its citizens so that their rights will not be jeopardized. In the area of civil law, the investment by the state is not as extensive as in that of social and economic rights, where the state is called on for a commitment to its citizens to provide them with minimal financial means for survival, as well as the right for education, medical treatment, work, and leisure. These social rights should counterbalance the legal rights for freedom, because allowing civil rights can result in gross inequality of individual wealth. For this reason, in the international declaration of human rights announced by the General Assembly of the United Nations in 1948, a general consensus was reached by the participating delegates that social rights are an integral part of civil rights. In spite of this, many formal bodies such as Amnesty International concentrate on civil rights only and do not get involved in social rights. This has resulted in an emphasis on civil laws without giving due regard to the fact that "a hungry person", a person with no means of economic survival, cannot benefit from "freedom of speech" or "freedom of association". Thus, an argument can be put forward that the social rights should indeed precede civil rights. Furthermore, some areas can be considered as belonging to both categories: the civil and the social. For example, work is at the heart of the dispute as to what are civil and political rights and those that may be characterized as social and economic. Work includes issues such as the right to safe and healthy working conditions, the illegality of slavery, or any other forced or compulsory labor. Connected with work are also the rights for leisure, the right to holidays with pay. Work, like leisure, has not yet become part of the civil and political rights legal system. This state of affairs is criticized by Beddard (1993) who points out that "just as one can argue, however, that the right to life may be negligible without the right to seek work, similarly freedom to grow up and enter into the social life of the state may be pointless without the opportunity to turn one's life into something worthwhile or to get involved in 'doing one's own thing. . . (ibid, p. 114). Civil and social rights are both designed to enable that which "the framers of the the American Declaration of Independence dubbed 'the pursuit of happiness' and what Article 22 of the Universal Declaration of Human Rights in 1948 means when it refers to the free development of personality" (Beddard, 1993, p.95).

Another important contribution to the international human rights law is The European Convention for the Protection of 
Human Rights and Fundamental Freedoms, which was signed first in 1950 and is part of the Council of Europe. The council includes not only the traditional Western states but since 1990 also several from Central Europe such as Czechoslovakia, Poland, Hungary, and Bulgaria. The European Convention, a reaction to the Second World War, is a political as well as a legal instrument. It presents the "rights which go toward the fulfillment of personal hopes, aspirations and ideals. Article 8 of the Convention requires respect for private and family life, home and correspondence. Articles 9 and 10 guarantee the freedom of thought, conscience and religion and the freedom of expression, while Article 11 secures the right to meet with others. . There are necessarily restrictions on these particularly personal rights, especially where the manifestation of individual wishes clashes with the rights of other persons. . . The democratic ideal upon which the European Convention professes to have been built means that the authorities need to pay attention to the wishes of the people and, in most cases the majority of the people, in legislating for and administering the country. Within each of those rights protected in Articles 8 to 11, therefore, the balance between the rights of the individual and those of the other members of the community must be struck" (ibid, p.95). In the United States, an American Convention on Human Rights was instituted in 1978 and has become the Inter-American Court of Human Rights.

One area which is especially relevant to persons with disabilities and where a balance is sought between, at times, conflicting interests relates to the issue of equality versus freedom. Indeed, depending on the interpretation of these two concepts, freedom and equality can be conceived as being mutually exclusive - the more freedom one has, the less equal he is with others. The old Communist regime emphasized, on the other hand, that equality should be based on the concept that every citizen should get the same from the state. Accordingly, all men should be treated equally, and all should receive exactly the same from the state, irrespective of personal differences. In the Western world the right for freedom was seen as dominant. Equality meant that equals must be treated equally, and unequals - differently. Distinctions between people and groups should be made if there are relevant differences between them. "Equity or justice rather than flat equality demands that men should be treated differently if there are relevant grounds for so treating them. Injustice results just as much, as Aristotle pointed out, from treating unequals equally as it does from treating equals unequally" (Peters, 1968, p. 118).

Equality can also be conceived as the right to use whatever is available, which means open opportunities for all. Equality is then "equality of opportunities". In comparing the educational system in the U.S.A. and in England, Peters notes that each uses another interpretation of the concept of equality: "In some countries, e.g. the U.S.A., education at any rate up to high school level is regarded almost as a kind of commodity to which all have an equal right. . . Selection is delayed and works rather like a free market economy on the basis of the survival of the fittest. It approximates to what Turner calls a 'contest' system in which all can have a go and see how far they can get. . . In such a system agitations about equality center round the injustice done to those who are, for irrelevant reasons, deprived of their right to what is available for all. . . In the English system, the necessity for different categories of education was generally accepted. There was not the presumption that children should all go to the same school. . . Differences in educational provision were accepted; the problem was to determine relevant grounds for assigning children to different schools" (ibid, pp. 131-132).

Another aspect of the concept of equality is seen as a legal principle, meaning equality before the law. When a person is brought before a court of law, he is entitled to fair treatment irrespective of his background. This calls for no discrimination based on "race, color, sex, language, religion, political ideas, or any idea in other matters, nationality or other social background, wealth, birth or other social status"The International Declaration of Human Rights (1948). Mikochik, 1991, in his foreword to a Temple University Law School Symposium on the Americans with Disabilities Act (ADA), used the title of: "A Celebration of Equality". He stated that: "The ADA (enacted in 1990) is long overdue. It will, at last, make millions of disabled persons full partners in our society. The ADA leads us rather toward the goal which has always guided our country: that all of us are created equal and endowed with an inalienable right to human dignity. . . Our path to equality has been halting. The Constitution endured slavery until the Civil War, and the benefits accomplished by the War and Reconstruction were squandered in a 'separate but equal' society where separate was guaranteed and equal was ignored. In the Civil Rights Act of 1964, Congress broke almost a century of silence to declare that the races must be treated equally in public schools, in public places, and in employment. . Y Yet, equality of millions of disabled citizens had been deferred. . . Disabled people had been placed on a kind of probation to prove their equality-even to some champions of civil rights who believed at first that, unlike race and sex, "such non-suspect statuses as intelligence or physical disability' frequently bear some 'relation to ability to perform or contribute to society'. Two decades of struggle have set these concerns aside, bringing an end to a probation which never should have been, and enabling us to again celebrate equality. With the passage of the ADA, the United States has recognized disabled people as full and equal citizens and has secured this principle in law" (Mikochik, 1991, pp. 371-372). 
Another issue concerning the concept of equality is the distribution of services. Indeed, the slogan of the French Revolution referred not only to Freedom and Equality but also to Fraternity, brotherhood. Modern social welfare states provide a certain cover for the basic needs of the individual especially in the areas of education, health and minimal living resources. Equality here means that in the distribution of resources and services there should be no discrimination between groups or individuals. Equality here is both an end in itself but also a means to a more equal society. A question raised here concerns the issue of reverse discrimination, which means that in order to fight inequality groups that have long been subjected to discrimination will be given priorities and in 'affirmative actions' be treated in a more favorable way, unequal to the rest of society. This point is especially relevant to persons with disabilities whose starting-point in society is lower than the rest of the community. As Herr (1992) asks in his overview of human rights and mental disability regarding international standards: "How are universal rights to be understood when applied to segments of the population who are defined by characteristics which tend to focus on their limitations? ... Persons with mental disabilities or persons regarded as disabled too often face threats of oppression and unjustified loss of liberty, but they have equally pressing claims to protection from poverty and neglect. By identifying those claims as human rights, the legal system can recognize a set of universal norms for a class of persons subject to special vulnerabilities, promote standards for their domestic legal protection, and apply those standards with rigor and consistency. The international community has begun that enterprise at both the nongovernmental organization (NGO) and United Nations (UN) levels. To date, the primary vehicle for this activity has been declaration-making. The pioneering Jerusalem Declaration on the General and Special Rights of Mentally Retarded Persons was promulgated by the International League of Societies for the Mentally Handicapped (ILSMH) in 1968. This NGO declaration then served as the inspiration and model for two UN human rights declarations concerning disabilities. In 1971, the UN Declaration on the Rights of Mentally Retarded Persons, in terms nearly identical to the ILSMH text, was adopted. . . In seven concise articles, it proclaims that the mentally retarded person has 'the same rights as other human beings', as well as rights to developmental services, 'a decent standard of living', normal modes of life, protective services, legal protection from 'abuse and degrading treatment', and 'proper legal safeguards' when any rights are restricted because of incapacity. Four years later, the UN Declaration on the Rights of Disabled Persons called for international and national action to protect the rights of all physically and mentally disabled persons" (ibid, pp. 146-147).
A special place in human rights considerations is given to the child. The human rights of children, like those of adults, are also based on the concept of what the nature of childhood is. For many generations the child was conceived as an incomplete human being. Indeed, the old religious point of view was that the child had to learn two major things: one, to control his drives and impulses; second, to be initiated into faith. The assumption was that children, unlike educated adults, could not resist temptation and were therefore sinful by nature, though this was forgivable because they were in the process of learning how to behave in a proper way. They should listen to their teachers and obey adults without questions or arguments. For this reason, children were not entitled to have legal rights, although they were also without legal duties.

In the old Greek philosophy, children were also regarded as incomplete creatures. The assumption was that because children had no capacity for rational judgement or for critical thinking, and they followed their drives and indulge in pleasures escaping from pain and effort, they were immature creatures who had to obey their elders. A combination of this approach and old Judeo-Christian religious assumptions resulted in a view of the child as the symbol of evil. During the Middle Ages and up until the period of the Enlightenment in the 18th century, childhood was regarded as the source of wickedness, and it was the aim of education to free the young from evil-doing and from ignorance. Children with disabilities were seen as doomed to a life of sin and illiteracy. All children were therefore without rights as well as without duties and were expected and obliged to show complete obedience to authority.

During the 17th century, with the new advancements in technology and industrialism, a new concept of childhood appeared. An analogy was made between people and machines, and the human body was perceived as operating according to mechanical laws. Children were regarded as amusing, somewhat like mechanical toys. Their ideas were considered as erroneous and limited, their spirit dull. The opinion that children had to obey the adults who could guide them until they matured, remained unchanged. Harsh discipline was the lot of most children. During the 18th century, with the rise of the state, new considerations regarding children evolved. The criteria applied were in line with the new political spirit of citizenship. Children were evaluated according to the extent to which they contributed to the economy and military strength of the state. Because the children's contribution was minimal, their social value was also small; it was expressed in the fact that child labor was not regarded as immoral or wrong. It should also be noted that since medical knowledge was less advanced than it is nowadays, a large percentage of children simply died in childhood. 
Children with disabilities were regarded as even less "valuable" because they were not seen as capable of contributing to the economic or military strength of the state. For this reason the investment in these children was not regarded as worthwhile. Like other children, they had no rights and no duties.

It was only in the second half of the 18th century that one began to hear a new voice calling for freedom, equality, and human dignity, and such concepts came to be applied to children also.

For the first time the idea that the child also had rights was heard. An important contribution to the change of attitudes toward childhood was the book Emile written by Rousseau (1762) and the ideas it presented regarding the nature of childhood, its value and the beauty of this period of life. De Monvel in his modern introduction to Emile (1966) points out that Rousseau's "remarkable intuition prepared the way for the subsequent inquiry and experimentation that have achieved so much in the sphere of education. The reader (of Emile) will find that it (this intuition) is responsible for all that is most original and most productive in Emile: maternal feeding, bodily freedom of the baby, physical training of the child, development of the senses, exercise of the judgment through sensory experience and contact with things, the approach to abstract knowledge by way of observation and experience. All these points derive from the initial view that an educator must submit to the development imposed by Nature. But it should not be forgotten that Rousseau considers submission to the natural order not only as a necessity of method, but as implied at the very end, the moral accomplishment of education" (ibid, p. vii-viii). It took two more centuries, though, for these novel ideas to be implemented in practice and in legislation.

At that time, the state began to take over from parents some of their duties for the education and preparation to adulthood of children. The latter were still regarded as being incomplete and in need of training and restraining in order to become contributing adults in the society. During the 19th century laws for compulsory education were passed in several Western countries, limiting the authority of parents over their children and reinforcing the power of the state over the fate of the young. In the early 20th century we see a significant change in the balance of power between parents and state regarding the education of children. Parental duties were reduced to obeying the state education system. However, new humanistic ideas began to be applied to childhood. The work of the early psychologists that described and analyzed the special features of childhood had an important and most significant contribution to the understanding of the unique nature of childhood, childrens' special needs, and the crucial place that childhood experiences have for the future development of the person.
However, it is only from about the middle of the 20th century that we witness a change in the concept of the legal rights of children in general, and children with disabilities in particular. In 1948 the Universal Declaration of Human Rights recognized the rightful claim of children to special care and assistance. It was not until 1989, however, that an article concerning the Rights of the Child was added to the already existing United Nations Convention on human rights. In Europe, the provisions of the European Convention apply to all individuals, irrespective of age, but the assumption is that just as old age may involve dependency on other people, so the child is always subject to the domination of his or her parents or guardians. In cases of conflict between parents and the authorities, the principle is that the interest of the child should take precedence over any private interests of either parent or the convenience of the authorities (Beddard, 1993). The issue of the legal rights of children is a complicated matter, and in many cases the state intervenes only after a gross abuse has been committed toward the child by his family or other adults. One aspect, though, of the child's development in which the state does intervene is his education. Accordingly, the law states that no person shall be denied the right to education while respecting the religious and philosophical convictions of the parents. A special article of the European Convention regarding the child's right to education indicates that this right must also include official recognition of the possible side-effects of compulsory education. A particular type of teaching or education may affect the family life of the child; if, for example, no proper school is available near home, the child might have to travel long distances for his education. Or the problem of mainstreaming of children with disabilities in the local school as against sending them away to a residential special school.

The issue of giving more credit to children and their opinions, more autonomy and respect, is still a complicated legal and social matter. Thus, even though changes occur nowadays, children face two obstacles: one is their credibility as autonomous and able persons as regards the state legal system, social and health services and the education system. The other is their status in the family and the balance of power between family and state. As we have seen, for many generations children were either neglected or seen as the property of their parents or the state. The idea of listening to children is made complicated by the recent trend to hear more what the family wants to say and regard the parents as having firsthand responsibility over the child, giving more weight to their opinions vis à vis state officials. Parents are therefore regarded as the official spokespersons for the child, and so his voice is not always heard. Another rather unexpected obstacle that delayed listening to children is the professionals. With the rise of psychology and the social 
sciences, the notion that adults, with their knowledge of theory and research, know all about childhood became widespread. The phrase that, for at least half a century, has been too often used is: "the best interest of the child". The "best interest" was decided upon by adults, mostly professionals who, rather like medical doctors, knew what a healthy childhood should be and in what way it should be expressed. A change in this line of thought is slowly taking place. Legal rights of children are taking a priority over the scientific and theoretical statements. Davie (1993) distinguishes between the two terms: a child's best interests and his/her rights. ". . . the term rights goes straight to the heart of the matter in asserting the child's autonomy or self determination" (ibid., p. 256). While professionals believe that they always act "in the best interest of the child," this should not be a substitute for rights.

Another legal issue relates to the question of age and the ability of children to present their views truthfully and coherently. In general, the imperative of respect for children, as for adults, entails that their views will be taken as truthful and sincere. Indeed, in England, a central principle of the Children's Act of 1989 is that "a child's perspective must be taken seriously and given due weight. This principle is now therefore a central and mandatory feature of social services policies and procedures and of child law, including family proceedings. It has also impinged upon important parts of the criminal justice system in Britain in recent years. In addition, I suggest, this principle is currently pushing at the frontiers of good practice in education and even in child health" (Davie, 1993) (p. 252). The author explains what listening to the child entails: it means communication and feedback and heeding to what children have to say in terms of their own evaluation of what is done to them and with them. It also means a legal aspect of whether, and at what age, a child can be accepted as a witness in a court of law. In the social services and in education, listening to the child is in line with current trends toward more consumer orientation, in our case children and their parents. The Children's Act goes even further to entitle the child to refuse assessment: "the Act lays down that the child may, if he is of sufficient understanding to make an informed decision, refuse to submit to the examination or other assessment. In this, the court may no more overrule the child than may the parent" (ibid., p. 253). As regards children with special needs, Circular 22/89 of the Department of Education and Science referred to the question of consulting pupils with special educational needs: "Older children and young persons should be able to share in discussions on their needs and any proposed provision . . . children have vital information to contribute to their own assessment, and their own attitudes and ideas are likely to affect the outcome of the plans being made for them. Further, they have a right to be actively involved in the assessment process" (ibid., pp. 255-256).
In the UN Convention on the Rights of the Child (1989) several articles deal specifically with the child with disability. "Article 23, for instance, specifies the rights of mentally and physically disabled children to a wide spectrum of rehabilitation services and special care. First, the article recognizes that such children 'should enjoy a full and decent life', with conditions promoting dignity, self-reliance, and 'active participation in the community'. Second, ratifying nations recognize, with various caveats, the child's right to special care appropriate to the individual's condition and the parental or other caregivers' circumstances. Third, in recognition of the disabled child's 'special needs,' this care and assistance 'shall be designed to ensure that the disabled child has effective access to and receives education, training, health care services, rehabilitation services, preparation for employment, and recreation opportunities in a manner conducive to the child's achieving the fullest possible social integration and individual development. . . Under other relevant articles, states recognize the child's right to periodic review of treatment when placed for purposes of care or treatment of physical or mental problems, right to education, right to health and treatment facilities, and right to the nondiscriminatory enjoyment of declared rights irrespective of the child's disability or other ascribed status. The Convention calls for strong protection for the institutionalized child ... . the Convention reflects a strong resumption against out-of-home institutional treatment and preference for 'a family environment' when residential treatment is required. . . In strikingly emphatic terms, the child is accorded a right to privacy and family integrity and protection of the law against interference with these rights" (Herr, 1992, pp. 149-150). We see, then, that children with disabilities should receive special consideration under the law in order to ensure that their basic human rights are met.

The concept of equality, therefore, should be regarded as a multi-dimensional concept. It includes the right to have open opportunities, the right for non-discrimination, as well as the right for protection against abuse and neglect and the right to receive differential help on the basis of relevant grounds.

The combined model of the hierarchy of support systems for persons with disabilities, to be presented in the next section, is based on this conception of equality and its foundation in human natural rights for dignity and for freedom.

\section{The Hierarchy of Human Rights for Care, Treatment, and Education}

In affluent societies, such as most nations in the Western world where social services and medical care are offered to citizens, the humanistic-educational model is to be regarded as the means and the aim of services. A revision of the custodial-welfare and the scientific-medical models of services 
and, consequently, their modification, seem to be called for. This may provide the answer to the dissatisfaction with the current state of the services and will ensure that in each and every case, the individual will be able to reach his/her utmost psychological growth, fulfill his/her potential, and lead a life of quality. This was clearly stated by Dillon (1993) in his presidential address to the American Association on Mental Retardation: "If our past can be described as the dominance of service over rights, wherein one had to sacrifice one's rights to receive the service, I suggest that our present focus on choice may entail the opposite, the dominance of rights over service and supports. In this paradigm, supports and services will be provided to the extent that one exercises one's rights. Yet we know that among those we serve, many cannot exercise their rights-some because they lack the capacity to communicate or to understand the issues involved, others because they have not had sufficient experience in making choices and or evaluating alternatives. Paternalism has no place in an era of empowerment. However, we can play a significant supportive role in helping others speak for themselves. We can cultivate conditions that foster choice and freedom. Although we cannot walk in someone else's shoes, we can offer a helping hand and we can walk along with that person" (ibid., p. viii). It seems that a conceptual change should take place regarding the theory and practice of special education and rehabilitation.

The question to be asked here is: If we wish to introduce a change, what kind of a change will it be?

In principle, the very first change that should take place is in the conception of what constitutes "services". The custodial-welfare model is based on the concept of services as giving material goods, as providing concrete things in order to help the client. In the scientific-medical model, services are identified with treatment aimed at the health and normalcy of patients. According to the humanistic-educational model, services are processes of education and support; they apply to all human beings, not only to "clients" or "patients." It is therefore suggested that the term "services" be discarded and instead the term "supports" be used.

Historically, the humanistic model was the last one to develop as an approach applied to all people, let alone those with disabilities. It is only in our modern times that the concept of human natural rights has become the underlying legal basis of nations, as it is seen in the Western world. However, it should be remembered that the origins of all three models, the humanistic, the custodial, and the scientific can be traced to approximately the same period of about 2500 years ago around the Mediterranean.

Looking at the evolvement of the three models of services, one can ask whether in the area of human support we should get rid of the custodial-welfare model and the scientific-medical model in favor of the humanistic-educational model? Obviously we cannot and we should not: social welfare services operate in Western countries, guarding and promoting the welfare of persons with disabilities; medical and psychological services provide health care to citizens. It is therefore proposed to combine the three models in a hierarchical form. The first level is mainly composed of the welfare approach; the second is basically that of the scientific approach; and the third of the humanistic. The value of social welfare to persons with disabilities as it originated in the Judeo-Christian religion is unquestionable. The provision of supports that cover basic human needs such as food, shelter, and security is the very first step up the ladder of support systems to people with disabilities. The most important contribution of the scientific-medical model lies in the relative control it affords people over the functioning of their body and soul. Science and technology have contributed enormously to health in general and to the physical welfare of persons with disabilities. However, it is the humanistic-educational model that enables man to lead a meaningful life. Personal and unique growth is the most significant contribution of this model. For the first time in Western history, persons with disabilities are considered as complete and full human beings, albeit with disabilities and handicaps. Respect for any person is the principle underlying this model. A holistic approach aimed at enabling each person - irrespective of disability - to develop a unique personality, give an outlet to individual skills and inclinations, exercise free choice concerning a style of life, and to be autonomous, are the main features of this model.

In addition, there is one other special feature that distinguishes sharply between the humanistic-educational model and the other two. While care and treatment are defined, and limited to specific situations, education is a lifelong process. A humanistic point of view is not related to a single, clearly defined and regulated situation; rather it is a way of life. For this reason the humanistic-educational model is both an end and a means. One cannot lead a humanistic way of life without education. Education is based on the humanistic principles that every human being has an innate potential for growth. This is a long process, starting from birth and ending at death. It is acknowledged, though, that a "hungry person" cannot fulfill his human potentials, and a "sick person" cannot express his potential and develop it. The foundation for the best expression of the humanistic approach is, therefore, social welfare followed by medical and psychological treatment.

For this reason, when considering of what kind of a change should be recommended, the answer is that what is called for: is a new balance in the priorities of the supports as a whole, and a new balance in the focus of each. This new balance of emphasis as a focus and priorities should be introduced both at the national, macro level of provision, 
and at the direct care, the micro, person-to-person level. At the macro level a re-evaluation should be made of the national system of supports in order to minimize custody and limit medical intervention to issues relating to highly specific and clearly defined matters of care and health only and widen the scope of the humanistic-educational approach. At the interpersonal, micro level, of everyday work, direct care staff and professionals should ask themselves: "To what extent can I find a humanistic alternative to issues that hitherto received answers only in a custodial or medical manner." For example, a welfare officer, the "middle-man" between the provision of welfare supports, including budget and material goods, and the client, can ask: Do I listen to my clients? Do I interact with them in a way that respects their specific style of life while at the same time I show them reality as it is, expecting them to respect me and my constraints too? Another instance: a psychologist can ask himself: Is my kind of therapy in line with the needs of this client or would another expert be more appropriate? Simple questions? Not really, when one is genuinely involved in a re-evaluation of one's outlook. New alternatives of response call for new attitudes. In order to foster a new balance, the first step is self-awareness based on knowledge of the major features of each type of service and the way they can be transformed into supports and operate as a combined system.

The proposed system of hierarchy of supports can be shown as three triangles, one located inside the other as shown in Diagram No. 1. The three corners of the triangles are: at the bottom, at one side, "society" and at the other side, "culture"; at the top pole "the individual person". The society-person axis is composed of domains that start with social conventions, social criteria for health and happiness, independence, leading up to autonomy and individual judgments as to what, for each particular person, means success and happiness. It is the axis that leads from social norms to moral values. In the area of disabilities, this is the axis of the transition from the principle of normalization to the concept of quality of life.

The second axis is that of: culture-person. It is composed of domains such as knowledge, skills, arts and science leading up to a personal view of life and an outlet to individual competencies. This is the axis that leads from technology to philosophy, from general skills and knowledge to the expression of individual talents in art, literature, and the sciences.

At the bottom of the hierarchy of the system of supports, at the center of the triangles, the custodial-welfare approach is to be found as the basis for the principle of social welfare. Following that, we see the scientific approach and the principle of health and normalcy. Finally, over both triangles is the humanistic approach and the principle of respect for each person.
Figure 1 demonstrates that all three models affect the way in which supports are provided to persons with disabilities. Though the custodial-welfare was historically the first to crystallize and be applied in a general way to the population (and it is still dominant in social welfare), the scientificmedical model is also included as a basic service to be provided to all citizens. The humanistic-educational approach is best seen in educational establishments, in compulsory education for all. Though local cultural interpretations affect the way the three models are conceptualized and practiced in each country and in each community, it is suggested that when policies are considered and defined and new laws are enacted, priorities will be given to humanistic-educational principles, without neglecting the lights for economic and health supports.

For this reason, the diagram represents the three models as three triangles, one inside the other. As we proceed up the triangle, the external triangle of the humanistic-educational model becomes, more pronounced. In fact, once the custodial and scientific principles are exhausted, the humanistic model remains the one that should underlie the way support is provided. At the peak, the top, the person becomes autonomous; the support the individual person asks for is unique, according to a personal style of life and values. It is then that social welfare and medical psychological services can be transformed into a system of supports that each person can use according to specific needs. Each one is not a nameless recipient, just one element in a specific group of people.

The autonomous person is seen as the one for whom the system of support is not a scaffolding but, rather, it serves as a crutch, individually adapted and operated by the person himself. Humanistic principles call for mutuality of respect between persons, between those with disabilities and those without. Basic or natural human rights are based on the concept of the dignity of each and every human being. Dignity implies that there is reciprocity of relations; it means that even the one receiving support should be respected as a contributing human being, as someone who has something to offer to others, and not merely as a recipient. This point is crucial for a humanistic interpretation of the new general policies of "legal human rights", "empowerment", "a person-centered approach", and "inclusion". These should not be mistaken as indicating a one-sided approach in which the person with disabilities becomes the only frame of reference for decision-making, like a spoiled child. Respect for a person means that the person with disabilities, an adult or a child, is perceived as being capable of understanding reality, is capable of self-control, capable of giving and of being responsible.

The hierarchy suggested here of human rights for care, treatment, and education can be seen as parallel to Abraham 


\section{THE INDIVIDUAL PERSON}

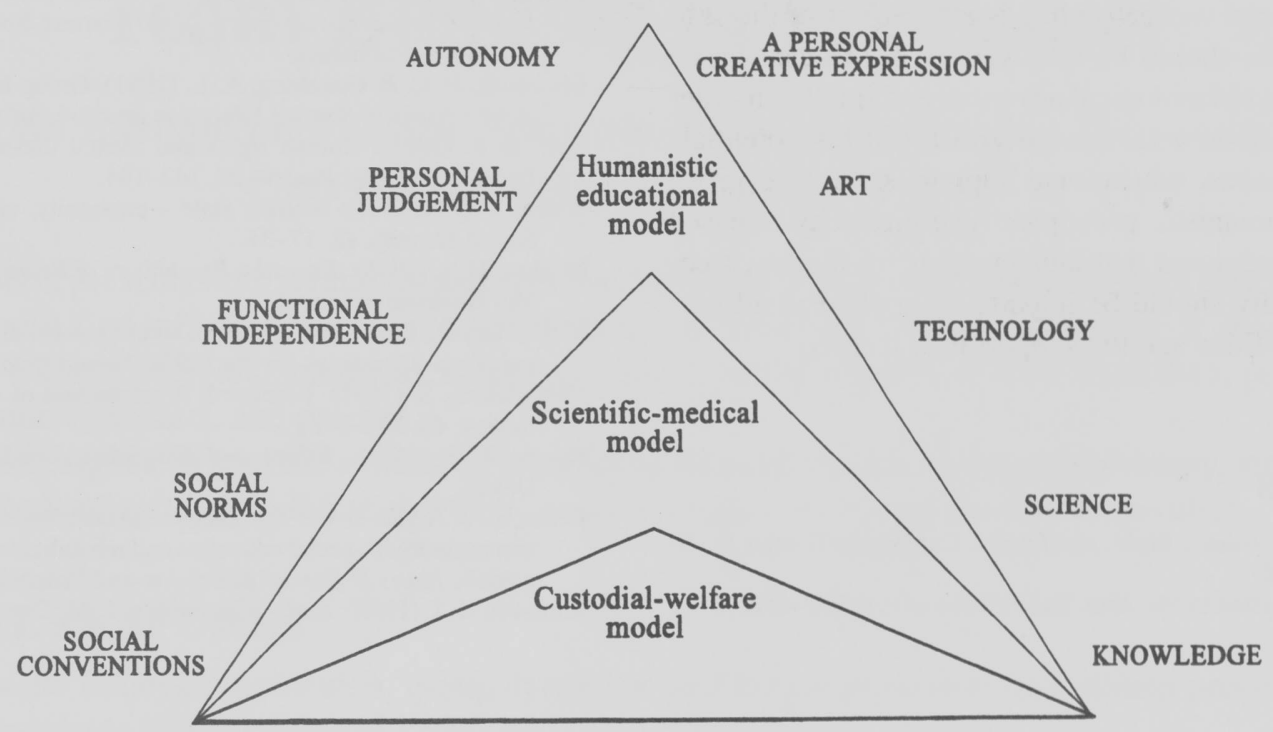

SOCIETY

CULTURE

FIGURE 1

The Hierarchy of Supports in Special Education and Rehabilitation

Maslow's (1968) hierarchy of the five universal basic needs: survival, security, belonging, self-worth, and self-actualization. However, Maslow's hierarchy is based in psychological thought and therefore the terms used are "human needs". It is a description of human nature, in line with psychological science. The similarity stems from the fact that human needs and human rights are both based on the humanistic conception of humanity. What differentiates the present paradigm from the "hierarchy of needs" is that its foundations are to be found in philosophy and in a certain set of coherent values and their implications regarding the issue of the meaning of life. The terms used are therefore "values" and "legal rights".

The combined model of a system of supports suggested here is based on knowledge of past and present, awareness of different conceptual and practical alternatives in services as they evolved and as they operate nowadays. Finally it calls for self-analysis: why do I do what I do and for what? In order for current services to become a system of supports according to personal needs, the hierarchy suggested here should be implemented both within and between existing services. It is then that terms such as "ideals" and "potentials" will turn out to be not empty phrases leading to empty rhetoric; rather, they will be operationally defined, their content established and expressed in practice. For example the term "meaningful life" is differently defined in each of the three models presented. Meaningful life in the religious sense is the one in which the person strives all the time to lead a "good" life; a meaningful life according to the scientific approach is the one in which the individual questions conventions and superficial knowledge and leads a life of "open-mindedness" and continual analysis of situations; a meaningful life in the humanistic sense is the one in which the person searches for truth. Thus, according to all three models, the person is conceived as being in the process of search. The peak of the external triangle in the diagram should not be erroneously understood as meaning an end of a process or a certain achievement. The person with a disability, like everyone else, should also be regarded as involved in a continual process of search and learning, and as having the basic human right to indulge in a search for belief, knowledge, and meaning.

\section{SUMMARY}

The hierarchy of the rights of persons with disabilities for support presently suggested is based on three models of assistance: the custodial-welfare model as it is expressed in social policy, the scientific-medical model, expressed in the sciences of health and psychology as well as in technology, and the humanistic-educational model as seen in progressive 
educational establishments. It is suggested that a new balance be initiated incorporating all three approaches according to which social welfare policy is at the basis of the support system. This should be followed by health care based on scientific and technological advances and finally, in order to enable the person with disability to fulfill his potentials and be autonomous, educational support should be given according to humanistic principles. The hierarchy is based on the acknowledgment that human rights for dignity, freedom, and equality should be impartially applied to all persons with disabilities and the support they receive.

\section{REFERENCES}

Beddard. R. (1993). Human Rights and Europe. Cambridge: Grotius Publications Limited.

Davie, R. (1993). Listen to the child. The Psychologist, 6, 252-258.
Dillon, M. R. (1993). Morality and freedom: Challenges to a field in transition. Mental Retardation, 31, vi-viii.

Elliott, D., Mayadas, N. and Watts, D. T. (eds). (1991). The World of Welfare and Services in an International Context. Springfield, Ill.: Charles C. Thomas Publishers.

Gunzburg, H. C. \& Gunzburg, A. L. (1991). Group homes Neoinstitutionalism? Issues in Special Education and Rehabilitation, 7,7-19.

Herr, S. S. (1992). Human rights and mental disability: Perspectives in Israel. Israel Law Review, 26, 142-194.

Katan, Y (1994). The welfare state - continuity, change or dissolution. Social Security, 42, 17-34.

Maslow, H.A. (1968). Toward a Psychology of Being (2nd ed.). New York: Van Nostrand Reinhold.

McFadden, D., Burke, P. E. (1991). Developmental disabilities and the new paradigm: Directions for the 1990s. Mental Retardation, 29, ii-vi.

Mikochik, L. S. (1991). Foreword: A celebration of equality. Temple Law Review, 64, 371-375.

Peters, R. S. (1968). Ethics and Education. London: George Allen \& Unwin.

Reiter, S., \& Asgad, B. (1992). Theoretical analysis and comparison of current attitudes in special education and rehabilitation: An outline of three models. Issues in Special Education and Rehabilitation, 7, 113-126.

Rousseau, J. J. (1966). Emile. Cambridge: J. M. Dent \& Sons Ltd.

\section{PERMISSIONS AND COPYRIGHT}

All rights are reserved. No part of this publication may be reproduced, photocopied, faxed, stored in a retrieval system, or transmitted in any form or by any means, electronic, mechanical, recording or otherwise, without the prior written permission of the publisher.
Back issues are available for sale. Reproduction requires permission and payment of fees. It is illegal and a violation of federal copyright law to reproduce this publication without permission. Direct all inquiries to the permissions editor. 


\section{Team Building in Education}

\section{Alan Basham and Valerie Appleton, Eastern Washington University, Cass Dykeman, Oregon State University}

This new book presents both a rational and specific technique for improving teamwork in educational settings. You'll find information on creating effective teams and what makes them work. It shows how to increase collaboration and teamwork among educators, social workers, school counselors, psychologists, community leaders, and parents.

It is designed to provide a blend of research and organizational development theory, step-by-step processes for leading team-building meetings, and information to expand leadership qualities.

\section{SPECIAL FEATURES}

- Addresses the issues of motivation, group dynamics, and the progressive team-building process

- Includes handouts and experiential exercises

- Shows how to conduct booster sessions to help energize teams

- Presents the differences between being a manager, a pseudo leader, and a genuine leader

\section{CONTENTS}

1. Introduction

2. Creating Effective Teams

3. Pitfalls, Resistance, and What You Already Know

4. Team-Building Preparation

5. Beginning the Process

6. Assessment in Team-Building

7. Problem-Solving and Decision-Making

8. Goal Setting and Implementation

9. Conducting a Booster Session

10. The Ethics of Team-Building and Leadership

11. Building a Crisis Team

12. Training Team-Building Consultants

13. Conclusion

242 pages/9905/paperback/ISBN 0-89108-267-0/\$34.95

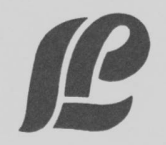

Love Publishing Company

9101 E. Kenyon Ave., Suite 2200

Denver, CO 80237

303-221-7333 • 303-221-7444 (FAX) 


\section{Professional update}

\section{NEW BOOKS \\ CONDUCTING EFFECTIVE CONFERENCES WITH PARENTS OF CHILDREN WITH DISABILITIES}

\section{A Guide for Teachers \\ Milton Seligman, University of Pittsburgh}

This book provides the knowledge and skills needed to conduct effective conferences with parents of children with disabilities. Readers gain a solid understanding of the challenges that families face as a consequence of childhood disability and the issues that are likely to arise in meetings with school professionals. Reviewing the basic elements of parent-teacher conferencing, Seligman highlights ways to develop strong listening and responding skills, establish rapport, and engage parents who may feel anxious, frustrated, or angry. Also addressed are the requirements of the legally mandated Individualized Education Program conference. Enhancing the book's utility are sample dialogues, role-play scenarios and exercises, and referral sources and publications suitable for recommendation to parents. ISBN: 157230-553-3 / Copyright 2000

Publisher: Guilford Press, 72 Spring Street, New York, NY 10012

\section{Council for Learning Disabilities}

October 19-21, 2000

Austin, TX

Contact: Kristen McBride, Executive Secretary Council for Learning Disabilities 913/492-8755 or KMcbr41457@aol.com

\section{National Association for Gifted Children}

November 1-5, 2000

Atlanta, GA

Contact: NAGC

1707 L Street, NW, Suite 550

Washington, DC 20036

\section{American Speech-Language-Hearing Association}

November 16-19, 2000

Washington, DC

Contact: ASHA

10801 Rockville Pike

Rockville, MD 20852 